\title{
Pengembangan Media Pembelajaran Berbasis Animasi pada Materi Fonologi untuk Mahasiswa menggunakan PowerPoint
}

\author{
1) Fatih Holis Ahnaf, 2) Farida Rochmawati, 3) Safira Hamdala, 4) Muzemil \\ 1),2) Dosen Tadris Bahasa Indonesia, Universitas Islam Zainul Hasan Genggong \\ 3),4) Mahasiswa Tadris Bahasa Indonesia, Universitas Islam Zainul Hasan Genggong \\ E-mail: fatihholis1212@gmail.com
}

Article History: Received: 2021-01-05 || Revised: 2021-02-15 || Published: 2021-03-02
Sejarah Artikel : Diterima: 2021-01-05 || Direvisi: 2021-02-15 || Dipublikasi: 2021-03-02

\begin{abstract}
Learning media in the 4.0 era should have become the premiere requirement for teachers who are directly involved with students and students. Teachers should have readiness to create learning media that are innovative, creative, and effective in supporting their profession. In this case the instructor can use the PowerPoint software as a media developer platform. PowerPoint is now equipped with new features that make it possible to make learning media more attractive and of course effective. This study aims to obtain objective descriptions of animation-based learning media on phonology material for second semester students of Indonesian Language Tadris, Zainul Hasan Genggong Islamic University in the 2020/2021 academic year. The development model used is the 4-D model which consists of (1) define, (2) design (planning), (3) develop and (4) disseminate. The instruments used were validation sheets and questionnaires aimed at users, material experts, and media experts. based on the results obtained from several validators $80 \%$ of users / users, $79 \%$ of material experts $88.5 \%$ media experts $82 \%$. Based on the obtained scores, animation-based learning media are valid, and can be used in phonology material for second semester Indonesian Tadris students at the Zainul Hasan Genggong Islamic University in the 2020/2021 academic year.
\end{abstract}

Keywords: Development, Learning Media, PowerPoint, Phonology.

\begin{abstract}
Abstrak
Media pembelajaran pada era 4.0 sudah seharusnya menjadi kebutuhan premier bagi pengajar yang terlibat langsung dengan siswa maupun mahasiswa. Pengajar seharusnya memiliki kesiapan dalam membuat media pembelajaran yang inovatif, kreatif, dan efektif dalam menunjang profesinya. Dalam hal ini pengajar dapat menggunakan software PowerPoint sebagai platform pengembang media. PowerPoint saat ini sudah dibekali dengan fitur baru yang memungkinkan untuk membuat media pembelajaran menjadi lebih menarik dan tentunya efektif. Penelitian ini bertujuan untuk memperoleh hasil deskripsi secara objektif mengenai media pembelajaran berbasis animasi pada materi fonologi untuk mahasiswa Tadris Bahasa Indonesia semester dua Universitas Islam Zainul Hasan Genggong tahun ajaran 2020/2021. Model pengembangan yang digunakan adalah model 4-D yang terdiri dari (1) define (pendefinisian), (2) design (perencanaan), (3) develop (pengembangan) dan (4) disseminate (penyebaran). Instrumen yang digunakan adalah lembar validasi dan angket yang ditujukan pada pengguna/user, pakar materi, dan pakar media. berdasarkan hasil yang diperoleh dari beberapa validator $80 \%$ pengguna/user, $79 \%$ pakar materi $88,5 \%$ pakar media $82 \%$. Berdasarkan pemerolehan skor tersebut media pembelajaran berbasis animasi valid, serta dapat digunakan pada materi fonologi untuk mahasiswa Tadris Bahasa Indonesia semester dua Universitas Islam Zainul Hasan Genggong tahun ajaran 2020/2021.
\end{abstract}

Kata kunci: Pengembangan, Media Pembelajaran, PowerPoint, Fonologi.

\section{PENDAHULUAN}

Kompleksitas pendidikan tidak terlepas dari perkembangan teknologi. Dua aspek tersebut harus disetarakan kedudukannya, karena apabila terdapat ketimpangan maka akan menghambat ataupun tidak tercapainya tujuan pendidikan. Begitupun peran pendidik, sebagai orang yang berhadapan langsung dengan mahasiswa, sudah seharusnya mengikuti perkembangan teknologi sehingga mampu menggunakan serta mengembangkan media pembelajaran yang inovatif, kreatif, dan efektif Sanjaya. (2014:101). Ada banyak keuntungan yang dapat diperoleh dari proses pengembangan 
sebuah media pembelajaran salah satunya yaitu meningkatkan kualitas pembelajaran, sehingga tujuan pendidikan bisa tercapai secara optimal. Kemp (dalam Susilana, 2009:9) mengatakan bahwa keuntungan dalam menggunakan media yang menunjang proses pembelajaran yaitu; (1) pembelajaran dapat lebih menarik, (2) kualitas pembelajaran dapat ditingkatkan, (3) waktu/timing pelaksanaan pembelajaran dapat diperpendek, (4) sikap positif terhadap materi pembelajaran serta proses pembelajaran dapat ditingkatkan. Dari pendapat tersebut sudah jelas bahwa banyak manfaat yang didapatkan dari pengembangan sebuah media. Namun kenyataan di lapangan tidaklah demikian. Setelah dilakukan wawancara dengan beberapa dosen, peneliti memperoleh data kualitatif berupa penyataan yang mengacu pada sumber permasalahan, diantaranya yaitu; (1) terlalu banyak software yang berkembang sehingga sulit untuk menentukan mana yang tepat dalam pengembangan media, (2) kurangnya minat, (3) memiliki minat namun belum mampu untuk mengembangkan maupun mengoperasikan software/sejenisnya.

Wawancara dilakukan sebagai tahap awal dari model pengembangan 4-D tepatnya pada poin pertama yaitu define (pendefinisian) yang memusatkan pada analisis kebutuhan pengajar. Ditinjau dari segi permasalahan dan analisis kebutuhan maka peneliti mencoba untuk dapat mengembangkan media pembelajaran dengan menggunakan software yang sesuai dengan tingkat kemampuan pengajar pada umumnya, yaitu PowerPoint. Dilihat dari segi fungsi PowerPoint adalah Software yang dirancang untuk kebutuhan presentasi, namun dengan beberapa pembaharuan yang dilakukan dari setiap versi terdapat keunggulan masing-masing. Saat ini PowerPoint bahkan sudah mampu membuat video berbasis animasi, desain grafis, dengan visualisasi yang baik. Adapun pembaharuan yang terdapat pada PowerPoint 2019 adalah; (1) model 3D, (2) export 4K, (3) transisi morph, dan (4) fitur perekaman http://support.microsoft.com/id -id/office/yang-baru-dipowerpoint-2019. keunggulan yang paling menonjol adalah morph transisi, karena dengan hadirnya fitur tersebut mampu memperhalus perpindahan antar slide menjadi lebih sinematik (Sianipar, 2018:2) Hal ini tentu memberikan kemudahan tersendiri bagi pengajar, maupun guru dalam mengembangkan media. Disisi lain pemilihan software ini didasari oleh kemampuan pengajar yang belum terbiasa menggunakan aplikasi editing video lainnya. Selain itu software ini bukanlah software yang asing karena sering digunakan dalam proses mengajar sehingga memudahkan guru dalam mengembangkan media pembelajaran yang kreatif, inovatif, dan efektif.

Format akhir yang dihasilkan dari pengembangan media pembelajaran ini adalah mp4/video berbasis animasi 2D yang dapat diakses secara online/e-learning. Arsyad (2014) mengatakan bahwa kemampuan e-learning bisa menjadi keunggulan, dan memberikan kemudahan belajar, terlebih di saat situasi yang mengharuskan untuk belajar secara daring. Media pembelajaran berbasis animasi tersusun dari beberapa komponen pendukung yaitu; voice over, gambar, karakter, dan efek suara. Selain itu dilengkapi dengan quiz pada setiap materi yang disusun menggunakan aplikasi google form sebagai instrumen untuk menguji pemahaman mahasiswa. Beberapa unsur kelengkapan media tersebut ditujukan untuk membuat media yang praktis digunakan, sehingga dapat menumbuhkan minat, maupun motivasi dalam belajar. Selain memotivasi pembelajar, Media yang dilengkapi dengan kemampuan visual yang dilengkapi dengan audio sehingga pembelajaran yang tadinya bersifat abstrak menjadi lebih kongkret Sadiman Dkk (2014:14). Hal ni tentu menjadi sebuah keunggulan tersendiri, terlebih pada materi fonologi yang kajian utamanya adalah bahasa lisan (abstrak) sehingga memerlukan penjelasan yang lebih kongkret. Maka dari itu pemilihan media pembelajaran berbasis video animasi dirasa tepat untuk mengatasi persoalan tersebut.

\section{METODE PENELITIAN}

Fokus penelitian ini adalah pengembangan media pembelajaran berbasis animasi pada materi fonologi untuk mahasiswa Tadris bahasa Indonesia semester dua Universitas Islam Zainul Hasan Genggong tahun ajaran 2020/2021. langkah awal yang dilakukan adalah melakukan analisis kebutuhan. proses ini diambil untuk menentukan seberapa tinggi tingkat kebutuhan mahasiswa terkait media pembelajaran berbasis animasi. setelah ditemukan tingkat kebutuhan mahasiswa, selanjutnya penentuan model pengembangan. Model Pengembangan yang diambil dalam penelitian ini adalah model 4-D Yang terdiri dari define, design, develop, dan disseminate. Setelah melalui tahap tersebut maka media pembelajaran di validasi oleh pakar materi fonologi dan pakar media pembelajaran. Kemudian media pembelajaran dilakukan revisi tahap pertama, Setelah dirasa cukup media pelajaran diterapkan pada kelompok kecil, kemudian dilakukan revisi kembali sampai 
memperoleh tingkat kesesuaian dan kelayakan yang ditargetkan. Berdasarkan rangkaian tahapan tersebut maka dihasilkan sebuah produk media pembelajaran berbasis animasi untuk materi fonologi. Adapun subjek penelitian ini terdiri dari; (1) Penggunaan/user Yang terdiri dari mahasiswa siswa kelas A semester dua jurusan Bahasa Indonesia Universitas Islam Zainul Hasan Genggong yang berjumlah 22 orang, (2) Pakar materi dengan spesifikasi pernah mengajar fonologi dan minimal pendidikan terakhir (S2) dan, (2) Pakar media pembelajaran dengan spesifikasi sarjana S1 pendidikan komputer. Sedangkan syarat untuk subjek uji coba pada penelitian ini adalah Memiliki smartphone, dan memiliki koneksi internet yang stabil. Sampling ini digunakan sebagai acuan dan masuk pada teknik sampling sistematis, dan purposif hal ini dikarenakan harus ada Beberapa syarat yang dipenuhi oleh subjek penelitian. Ini sesuai dengan apa yang dikatakan Setyosari (2015:225), Teknik sampling sistematis dan purposif dapat dilakukan apabila peneliti memiliki alasan maupun standar khusus yang berkenaan dengan penelitiannya atas dasar pertimbangan bahwa media pembelajaran animasi diuji coba secara online pada sampel 22 mahasiswa. Berkaitan dengan hal tersebut Sugiyono (2014:84) menyatakan kesepakatannya terkait ini, yaitu sampling sistematis dan purposif dapat dilakukan berdasarkan syarat ataupun pemilihan yang dilakukan oleh peneliti.

Data yang dimasukkan dalam penelitian ini adalah data kualitatif dan data kuantitatif. Data kualitatif kualitas diperoleh dari angket penilaian. Instrumen yang digunakan berupa angket, terdiri dari angket analisis kebutuhan, dan angket validasi. Angket analisis kebutuhan dijabarkan dalam deskripsi verbal yang diperoleh dengan bentuk, sangat setuju (SS), setuju (S), kurang setuju (KS), dan tidak setuju (TS). Sedangkan data yang diperoleh dari angket validasi berupa komentar maupun saran dari validator materi dan media. Hasil dari instrumen tersebut kemudian dijadikan sebagai dasar penarikan kesimpulan yang mengacu pada valid atau tidaknya media Pembelajaran yang dikembangkan. Informasi spesifik mengenai keberhasilan media pembelajaran yang dikembangkan dianalisis berdasarkan data yang terkumpul. Proses ini dilakukan ketika semua data telah terkumpul. Analisis dipilah menjadi dua jenis data (kualitatif dan Kuantitatif). Adapun teknik analisis data pada Kualitatif adalah; (1) Perampingan data mengacu pada peringkasan, pemilihan konten utama, fokus pada konten yang bersifat krusial, dan pencarian tema, (2) data dinarasikan secara ringkas, (3) Verifikasi yang meliputi proses penarikan kesimpulan sehingga merepresentasikan hasil dari data dan reduksi data. Kemudian untuk Menganalisa data kuantitatif peneliti menggunakan rumus yang (diadaptasi dari Sugiyono, 2014). Adapun rumus yang digunakan dalam penelitian ini adalah:

$$
P=\frac{\sum X}{N} \times 100 \% \operatorname{atan} N A=\frac{\sum P}{n}
$$

(diadaptasi dari Sugiyono, 2014)

\author{
Keterangan: \\ $P \quad$ : Persentase skor \\ $\sum X$ : Jumlah jawaban per responden untuk setiap pertanyaan / pernyataan \\ $N \quad$ : Skor total untuk jawaban tertinggi \\ $N A$ : Nilai Akhir \\ $n$ : Banyak butir pertanyaan/pernyataan \\ $\sum P_{\text {: Jumlah persentase skor }}$
}

\title{
III. HASIL DAN PEMBAHASAN
}

Penelitian yang relevan pada penelitian ini adalah metode pengembangan 4-D Hal ini dikarenakan metode tersebut memenuhi syarat pengembangan sebuah media pembelajaran. Adapun langkah demi langkah yang ditawarkan pada metode ini adalah define, design,, develop, dalam Trianto (2007:65), Tahap pendefinisian (define) tersusun atas tiga tahapan yaitu analisis ujung depan, analisis karakter dan, analisis materi. Pada analisis ujung depan memperoleh skor sebesar $65 \%$ mahasiswa setuju dengan media pembelajaran berbasis animasi, Analisis karakter 
memperoleh $60 \%$. Analisis materi dilakukan secara sistematis dan terperinci terkait materi yang akan menjadi bahan dalam media pembelajaran dengan menggunakan aplikasi PowerPoint. Materi yang dikembangkan dalam penelitian ini disusun untuk kebutuhan satu semester diantaranya; (1) fonologi dan cakupannya, (2) fonetik, (3) fonemik, (4) tahap, proses, transkripsi fonetis, (5) klasifikasi, deskripsi bunyi segmental dan suprasegmental, (6) fonem dan grafem, (7) perubahan bunyi (dalam Trianto:2010). Setiap materi yang dikembangkan dilengkapi dengan quiz pada masing masing-masing pertemuan. Quiz ini dilakukan dengan bantuan google form yang bertujuan untuk memudahkan peneliti dalam menganalisis data. Selanjutnya analisis ujung depan dilakukan untuk mengetahui tingkat kebutuhan pengajar/dosen, dari sini hasil yang diperoleh adalah 85\% dosen setuju dan perlu media pembelajaran yang inovatif, kreatif, dan efektif pada materi fonologi menggunakan PowerPoint sebagai media pengembangnya.

Tahap perancangan (design) Yaitu proses perancangan media pembelajaran yang diawali dengan pembuatan Flowchart dan Storyboard. Secara umum proses ini dilakukan sebagai langkah awal untuk mempermudah proses perancangan sebelum masuk pada Program PowerPoint. Adapun rincian dari tahap desain ini adalah membuat script materi, membacakan script materi dan dikonversikan menjadi format MP3, menyusun animasi, menggabungkan audio dan video animasi, serta proses export menjadi format video MP4.

Tahap pengembangan (develop) diimplementasikan dengan memberikan draft media pembelajaran berbasis animasi pada Materi fonologi kepada validator Instrumen untuk mengetahui kualitas pertanyaan dari angket yang telah disusun. Isi atau komponen yang ada dalam draft pakar materi pembelajaran meliputi uraian materi pembelajaran, soal latihan, kesesuaian tujuan dengan tingkat perkembangan mahasiswa, soal latihan, dan kaidah penggunaan Bahasa. Penilaian yang diberikan oleh validator materi berupa skor Kemudian dari nilai tersebut dihitung rata-rata pada setiap aspeknya. Spesifikasi minimal yang dibutuhkan untuk menjadi validator materi adalah dosen bahasa Indonesia dengan syarat pendidikan S2. Validator materi pada penelitian ini adalah Farida Rochmawati, M.Pd. Hasil dari analisis materi dengan kesesuaian tujuan diperoleh 78\%, konsep uraian materi $83 \%$, soal latihan $75 \%$, kaidah kebahasaan $80 \%$. selanjutnya skor dihitung dan diperoleh persentase NA/nilai akhir sebesar 79\%. berdasarkan skor yang diperoleh maka dapat ditarik kesimpulan bahwa materi media pembelajaran biologi berbasis video animasi dinyatakan valid. Sedangkan isi pada draf validator media meliputi Kesesuaian media pembelajaran dengan dasar desain, Kemudahan desain, keterbacaan teks. Syarat minimal yang dibutuhkan untuk menjadi validator media pada penelitian ini yaitu pendidikan minimal S1 Jurusan komputer. Adapun aspek yang dinilai dari pakar media adalah. Kemudahan, kemenarikan, kelayakan dari media pembelajaran yang telah dikembangkan.

Tabel 1. Kriteria pengambilan keputusan terhadap validitas media pembelajaran

\begin{tabular}{lll}
\hline $\begin{array}{l}\text { Persentase NA } \\
(\%)\end{array}$ & Kualifikasi & Keputusan \\
\hline $90 \leq P \leq 100$ & Sangat Valid & $\begin{array}{l}\text { Media pembelajaran berbasis animasi untuk uji coba di } \\
\text { lapangan/tidak revisi. }\end{array}$ \\
\hline $80 \leq P<90$ & Valid & $\begin{array}{l}\text { Media pembelajaran berbasis animasi untuk uji coba di } \\
\text { lapangan/tidak revisi. }\end{array}$ \\
\hline $70 \leq P<80$ & Cukup Valid & $\begin{array}{l}\text { Media pembelajaran berbasis animasi dapat diujicobakan, } \\
\text { dengan menambah sesuatu yang kurang, melakukan } \\
\text { pertimbangan tertentu, penambahan yang dilakukan } \\
\text { tidak terlalu besar dan tidak mendasar. }\end{array}$ \\
\hline $60 \leq P<70$ & Kurang valid & $\begin{array}{l}\text { Merevisi dengan meneliti kembali secara seksama dan } \\
\text { mencari kelemahan-kelemahan media pembela-jaran } \\
\text { berbasis animasi untuk disempurnakan. }\end{array}$ \\
\hline$P<60$ & Tidak Valid & $\begin{array}{l}\text { Media pembelajaran berbasis animasi gagal, merevisi } \\
\text { secara keseluruhan tentang isi media pembelajaran. }\end{array}$ \\
\hline
\end{tabular}

(diadaptasi dari Sudjana, 2009:124) 
Ketentuan yang ditetapkan untuk bahan media adalah sarjana S1 komputer. Dalam hal ini yang menjadi validator media adalah mahasiswa S1 lulusan Universitas ASIA Malang. persentase yang diperoleh dari aspek kemenarikan sebesar 80\%, kualitas media 87\%, kelayakan video pembelajaran $85 \%$, kemudahan penggunaan media pembelajaran sebesar 92\%. Berdasarkan nilai tersebut diperoleh nilai akhir dari keseluruhan analisa pakar ahli sebesar 88,5\%. Berikut ini adalah rumus yang digunakan untuk memperoleh nilai akhir N/A.

$$
N A=\frac{\sum P}{n}
$$

Keterangan:

NA : Nilai Akhir

$\Sigma \mathrm{P} \quad$ : Jumlah persentase skor

$\mathrm{n} \quad$ : banyak butir pertanyaan/pernyataan

Berdasarkan skor yang diperoleh maka dapat disimpulkan materi media pembelajaran fonologi berbasis video animasi dinyatakan sangat valid dengan catatan beberapa revisi pada materi fonetik sub materi jenis bunyi berdasarkan artikulator. Catatan revisi yang diberikan berupa pemberian animasi (pergerakan) pada artikulator aktif saat melafalkan bunyi Bahasa. Hasil uji coba yang diterapkan pada 22 mahasiswa Tadris bahasa Indonesia Universitas Islam Zainul Hasan Genggong memperoleh skor rata-rata $80 \%$ pada aspek kepraktisan. Hal ini ditunjukkan pada pemerolehan nilai rata-rata $84 \%$, dengan rincian, aspek kepraktisan 80,6\%, kelayakan isi 78\%, kebahasaan 80\%, tampilan dan kesimpulan $85 \%$. Selanjutnya berdasarkan pemerolehan skor dibagi dengan tiga aspek sehingga memperoleh skor akhir $84 \%$. Berdasarkan data tersebut jika disesuaikan dengan skor tabel yang (diadaptasi dari Sujana, 2009,124) maka media pembelajaran berbasis animasi untuk mahasiswa semester dua Universitas Islam Zainul Hasan masuk dalam kategori valid. Secara keseluruhan skor rata-rata yang diperoleh dari subjek penelitian berada di atas $70 \%$. Hal ini ditujukan oleh pemerolehan skor akhir dari pengguna/user sebesar 84\%, pakar materi 79\%, dan pakar media sebesar $88,5 \%$. Dari data tersebut maka dapat dinyatakan bahwa media pembelajaran berbasis animasi pada materi fonologi dinyatakan valid dan layak untuk digunakan.

\section{SIMPULAN DAN SARAN}

\section{A. Simpulan}

Video pembelajaran berbasis animasi pada materi yang dikembangkan berdasarkan analisis kebutuhan media pembelajaran terhadap materi fonologi hal ini ditunjukkan dengan pemerolehan skor pada saat analisis kebutuhan memperoleh angka 60\% yang menyatakan bahwa mahasiswa membutuhkan media pembelajaran sebagai alat bantu dalam memahami materi fonologi. Selain itu adapun analisis kebutuhan yang dilakukan adalah analisis kebutuhan dosen. Pada tahap ini, analisis kebutuhan dengan subjek dosen memperoleh deskripsi dan skor yang menunjukkan bahwa dosen membutuhkan media pembelajaran berbasis animasi untuk materi fonologi. Oleh dasar tersebut maka peneliti melanjutkan proses pengembangan media pembelajaran berbasis animasi untuk materi fonologi dengan menggunakan model pengembangan 4-D yang terdiri atas tahapan; (1) define (kajian awal) dilakukan untuk menentukan tingkat kebutuhan media pembelajaran, (2) design (perancangan) meliputi penetapan software yang akan digunakan untuk editing serta membuat flowchart dan Storyboard sebagai panduan pengembangan media pembelajaran, dalam hal ini program yang digunakan adalah aplikasi PowerPoint. (3) develop (pengembangan) meliputi tahap-tahap penyebaran instrumen serta penilaian dari validator instrumen, validator materi, validator media, dan pengguna/user. Selanjutnya tahap uji coba yang dilakukan pada 22 mahasiswa semester dua jurusan bahasa Indonesia pada materi fonologi Universitas Islam Zainul Hasan Genggong, (4) disseminate (penyebaran) dikarenakan keterbatasan waktu dan biaya maka pengembangan media pembelajaran ini belum sampai pada tahap tersebut. Namun media yang dikembangkan sudah melewati tahapan validasi dan memperoleh kategori valid serta layak digunakan untuk pembelajaran materi fonologi. 
Berdasarkan hasil pengujian hipotesis dan pembahasan yang telah dilakukan pada penelitian ini, maka dapat disimpulkan: (1) Terdapat pengaruh Kemampuan Take Off terhadap kemampuan Lompat jauh dengan rhitung 0,842. koefisien uji signifikansi hitung (th $=6,63$ ) yang lebih besar dari pada koefisien uji signifikansi tabel $(\mathrm{tt}=1,703),(2)$ Terdapat pengaruh Explosive power Otot Tungkai Terhadap kemapuan Lompat Jauh dengan $\mathrm{rh}=0,902$ dan koefisien uji signifikansi hitung (th $=8,86)$ yang lebih besar daripada koefisien uji signifikansi tabel $(\mathrm{tt}=1,73)$, (3)Terdapat pengaruh Kemampuan Take Off dan Explosive power secara bersama-sama terhadap Kemampuan Lompat Jauh dengan $\mathrm{Rh}=0,915$ dan koefisien uji signifikansi hitung $(\mathrm{Fh}=43,72)$ yang lebih besar daripada koefisien uji signifikansi tabel $(\mathrm{Ft}=$ 3,59).

B. Saran

Saran pemanfaatan/penggunaan media pembelajaran berbasis animasi bagi dosen yaitu; (1) Dosen/pengajar hendaknya menyusun dan mengembangkan media pembelajaran yang relevan, dengan tujuan agar target yang telah dirancang dapat tercapai, (2) sebagai fasilitator, dosen harus menyiapkan bahan dan alat dalam penggunaan media ini. Bahan yang dimaksud adalah laptop, proyektor, dan koneksi internet karena media pembelajaran ini dapat diakses secara online, (3) media pembelajaran ini sudah dilengkapi dengan quiz untuk tiap pertemuan, namun dalam hal ini dosen pengguna disarankan untuk membuat atau memodifikasi soal yang sudah ada agar sesuai dengan kebutuhan belajar. Bagi mahasiswa, media pembelajaran ini dapat digunakan sebagai sarana belajar mandiri dan mahasiswa hendaknya memahami dengan benar tahapan materi yang telah tersedia, karena materi pada mata kuliah fonologi bersifat prasyarat, maka jika melompati materi akan kesulitan memahami materi berikutnya. Kemudahan mengakses materi secara online diharapkan mampu membantu kegiatan belajar mahasiswa secara mandiri.

Saran yang ditujukan kepada peneliti selanjutnya, agar dapat melakukan penelitian di tahap penyebaran. Hal ini dilakukan agar peneliti dapat mengetahui sejauh mana efektivitas penggunaan media pembelajaran yang dikembangkan. Pada penelitian ini media pembelajaran yang dikembangkan masih sampai pada tahap uji coba kelompok kecil yaitu 22 mahasiswa Tadris bahasa Indonesia Universitas Islam Zainul Hasan Genggong. Disamping itu media pembelajaran yang dikembangkan ini sudah dapat digunakan pada tingkat universitas dengan jenjang semester dan materi yang sama yaitu materi fonologi dan semester dua. Adapun syarat penggunaan media pembelajaran ini adalah merujuk pada sampling sistematis dan purposif yang mensyaratkan agar menyiapkan bahan-bahan serta alat yang akan digunakan dalam proses pembelajaran dengan menggunakan media pembelajaran berbasis animasi pada materi fonologi. Benda-benda yang harus dipersiapkan antara lain smartphone dan koneksi internet yang stabil (online), laptop, proyektor, dan ruang kelas (offline). Salah satu keuntungan dari media yang dikembangkan ini adalah dapat diakses secara online melalui channel YouTube yang sengaja telah disiapkan untuk mempermudah akses mahasiswa terhadap proses belajar materi fonologi. Apabila digunakan secara offline maka akan jauh lebih mudah, dikarenakan dosen dapat berinteraksi mahasiswa secara langsung.

\section{DAFTAR RUJUKAN}

Arsyad, A. 2014. Media Pembelajaran. Jakarta: PT Raja PraGrafindo Persada.

Muslich, M. 2010. Fonologi Bahasa Indonesia Tinjauan Deskriptif Sistem Bunyi Bahasa Indonesia. Jakarta: PT Bumi Aksara.

Microsoft.com. (2019). fitur PowerPoint 2019. Diakses pada 15 Mei 2019, dari https://support.microsoft.com/id-id/office/yang-baru-di-powerpoint-2019-untukwindows-8355a56a-f643-42d2-8454-784fa9b3d109?ui=id-id\&rs=id-id\&ad=id.

Sadiman, A. Dkk. 2014. Media Pendidikan. Jakarta: PT Raja PraGrafindo Persada.

Sanjaya, W. 2014. Strategi Pembelajaran Berorientasi Standar Proses Pendidikan. Jakarta: Kencana PrenadaMedia Group. 
Setyosari, P. 2015. Metode Penelitian Pendidikan dan Pengembangan. Jakarta: PT Kharisma Putra Kencana.

Sianipar, P. 2018. Bekerja dengan PowerPoint 2016. Jakarta: PT Elex Media Komputindo.

Sudjana. N. 2009. Penelitian Hasil Proses Belajar Mengajar. Bandung: PT Remaja Rosdakarya.

Sugiyono. 2014. Metode Penelitian kuantitatif Kualitatif dan R\&D. Bandung: Alfabeta, CV.

Susilana. 2009. Media Pembelajaran, hakikat Pengembangan, Pemanfaatan, dan Penilaian. Bandung: Cv Wacana Prima.

Trianto. 2007. Model Pembelajaran Inovatif Berorientasi Kontruktivistik. Jakarta: Prestasi Pustaka. 